\title{
Chlorophyll fluorescence and initial growth of two liana species, Cuspidaria sceptrum (Cham.) L.G. Lohmann and Fridericia florida (DC) L.G. Lohmann, under changes of natural light conditions
}

\author{
S.M. PAULA*, M.A. BOSELLI**, and M.C. SANCHES*,+ \\ Instituto de Biologia, Campus Umuarama, Bloco 2D, Universidade Federal de Uberlândia, Rua João Naves de \\ Ávila 2121, CEP: 38400-902 Uberlândia, MG, Brazil* \\ Instituo de Física, Campus Santa Mônica, Universidade Federal de Uberlândia, Rua João Naves de Ávila 2121, \\ CEP: 38400-902 Uberlândia, $M G$, Brazil**
}

\begin{abstract}
The physiological alterations as well as the growth were evaluated in seedlings of two liana species, Cuspidaria sceptrum and Fridericia florida, which were transferred from shade to full sunlight conditions. We cultivated one group of seedlings under full sunlight, the second group under natural shade beneath canopy, and the third group was transferred from shade to full sunlight. Reductions on the potential quantum yield of PSII $\left(\mathrm{F}_{\mathrm{v}} / \mathrm{F}_{\mathrm{m}}\right)$ during predawn was detected under full sunlight, but these responses were more pronounced when the plants were transferred from shade to full sunlight. C. cuspidaria lost all leaves developed under shade a few days after transfer. However, at $60 \mathrm{~d}$ after transfer, new leaves were already developed and their $\mathrm{F}_{\mathrm{v}} / \mathrm{F}_{\mathrm{m}}$ values were similar to full sunlight plants. F. florida was able to maintain its leaves after transfer and exhibited gradual recovery of $F_{v} / F_{m}$ over time. The initial photoinhibition influenced growth responses of these liana species, in spite of their heliophyte character as adult plants.
\end{abstract}

Additional key words: biomass partitioning; light acclimation; nonphotochemical quenching; photoinhibition; relative growth rate; tropical semideciduous forest; specific leaf area; woody vines.

\section{Introduction}

Lianas (woody vines) are plants that are rooted in the soil and rely on other plants as support for its growth and ascending to the canopy (Holbrook and Putz 1996, Wyka et al. 2013). Lianas decrease the growth of their host trees (Putz 1984, Toledo-Aceves and Swaine 2007) and have the potential to modify the traditional successional process by supressing tree seedling regeneration (Schnitzer et al. 2000, Schnitzer and Carson 2010, Martínez-Izquierdo et al. 2016). On the other hand, when compared to trees, lianas produce leaf litter enriched with phosphorous which could increase the nutrient availability where these plants are abundant (Cai and Bongers 2007). Furthermore, lianas contribute to the evapotranspiration of seasonal forests (Restom and Nepstad 2001) and serve as a food source for animals and as a structural component of their habitat (Gentry 1991, Morellato and Leitão Filho 1996, Anbarashan and Parthasarathy 2013).

The presence of lianas represents an important characteristic that distinguishes temperate from tropical forests (Putz 1984, Gentry 1991, Schnitzer and Bongers
2011). A comparative study of floristic composition from several tropical semideciduous forests of the Southeast of Brazil found that lianas comprise about $52 \%$ to total wood species and that the mean similarity among forest sites was low (Santos et al. 2009). As pointed by the authors, these results reveal the importance of these plants for diversity maintenance of tropical semideciduous forests whose ecosystem has been threatened and fragmented by agricultural activities and urban expansion (Toniato and de Oliveira-Filho 2004, Prado Júnior et al. 2014).

Light varies continuously both in time and space in tropical semideciduous forests. Under canopy, the light intensity, which reaches the leaves, is extremely reduced and strongly depleted of photosynthetically active radiation and is high in the far-red region (Bazzaz 1979, Souza and Válio 2003). Conversely, the light environment in the interior of these forests may be drastically altered due to gap opening which can be created by the death of canopy trees or even by the fall of branches and leaves (Wirth et al. 2001, Nascimento et al. 2012, Venturoli et al. 2012, Souza et al. 2014).

Seedling survival and growth in these environments

Received 10 November 2017; accepted 23 April 2018

${ }^{+}$Corresponding author; e-mail: sanchesmc@gmail.com

Abbreviations: Chl - chlorophyll; DAT - days after transfer, DM - dry mass, $\mathrm{F}_{\mathrm{v}} / \mathrm{F}_{\mathrm{m}}$ - potential quantum yield of PSII, $\Delta \mathrm{F} / \mathrm{F}_{\mathrm{m}}{ }^{\prime}-$ effective quantum yield of PSII, ETR - electron transport rate, NPQ - nonphotochemical quenching, RGR - relative growth rate, FSU - full sunlight, SH-FSU - shade-full sunlight, $\mathrm{SH}$ - shade.

Acknowledgements: The authors thank FAPEMIG (Fundação de Amparo à Pesquisa do Estado de Minas Gerais) for financial support of this study, and Uni-Algar for providing the area for the experiments. Paula SM thanks Capes for fellowship. The authors are also grateful to anonymous reviewers for the constructive comments on the manuscript. 
depend on adjustments at all levels of organization. Under the canopy, it is common to observe increases in the quantum yield of PSII and modifications of biomass distribution that contribute to maintenance of positive carbon balance (Lavinsky et al. 2014, Lestari and Nichols 2017). On the other hand, in gaps or forest edges, plants are exposed to high light intensity which promotes increases in relative growth rates and in root biomass (Mazzanatti et al. 2016). However, in open areas, the increase in light intensity is followed by higher temperatures and lower relative humidity. Such conditions may predispose plants continuously exposed to full sunlight to stress known as photoinhibition, which comprises a set of complex reactions that can lead to the reduction in photosynthesis or even in growth (Krause et al. 2012). Photoinhibition can increase when shaded plants are exposed to sudden increases in light intensity (Lovelock et al. 1994, Naramoto et al. 2006, Azevedo and Marenco 2012). The possible photoinhibition damage at the moment of gap opening may be minimized if plants exhibit efficient mechanisms of acclimation (Naidu and DeLucia 1997, 1998).

Compared to species that require high levels of light for their growth, as the pioneers, the shade-tolerant species tend to be more susceptible to photoinhibition and have a lower acclimation capacity under high-light intensity conditions (Yamashita et al. 2000, Krause et al. 2001, Einhorn et al. 2004, Dias and Marenco 2006, dos Anjos et al. 2012, Rabelo et al. 2013). Based on demand for light, lianas have been considered pioneer clearing-dependent plants (Dewalt et al. 2000). Indeed, many lianas grow better in clearings. Such distribution pattern gives us indications that these plants require high irradiance for their establishment and development (Lüttge 2008). The capacity to fix more carbon per unit leaf mass mainly during the dry season, to drive electron flow to photorespiration and use water efficiently gives lianas some characteristics that allow them to survive in high-light environments (Sanches and Válio 2008, Cai et al. 2009, Zhang et al. 2016).

Nevertheless, there are many lianas that germinate, survive, and grow beneath canopies, suggesting that these plants have traits that promote some level of shade tolerance (Sanches and Válio 2002, Cai et al. 2007, Celis and Avalos 2013, Avalos and Mulkey 2014, Yuan et al. 2016). Regardless, it is unclear how lianas respond to sudden increases in light intensity and the magnitude of probable photoinhibition when lianas are faced with such increases. For instance, some lianas increased the photosynthetic capacity and biomass accumulation when transferred from shade to full sunlight indicating that these species are able to respond quickly to alterations in light conditions (Toledo-Aceves and Swaine 2008, Avalos and Mulkey 2014). Regarding the role that lianas exert on forest dynamics (Schnitzer and Bongers 2011), it is important to understand the physiological and morphological changes during the initial phase of their development, since these responses would impact the succession process of semideciduous forests (Letcher and Chazdon 2012).

Cuspidaria sceptrum (Cham.) L.G. Lohmann and Fridericia florida (DC) L.G. Lohmann are two liana species belonging to the Bignoniaceae family. C. spectrum occurs in several states of Brazil, in areas of the Cerrado Biome (Brazilian savannas) and dry rocky outcrops, while $F$. florida has a more widespread distribution including the Amazon rainforest and the Atlantic rainforest, and also in Cerrado Biome (Lohmann and Taylor 2014, Vasconcelos et al. 2015). Considering that lianas begin their life in the soil of a tropical forest and then ascend to the canopy, these plants may experience extreme differences in light intensity and spectral quality during their growth (Lee and Richards 1991, Celis and Avalos 2013, Avalos and Mulkey 2014). Within this context, the aim of this work was: (1) to determine the physiological alterations in these liana species under contrasting natural light environments (shade and full sunlight) in a semideciduous forest and (2) to evaluate the magnitude of photoinhibition and growth when the seedlings were transferred from shade to full sunlight conditions, simulating changes in the light conditions that are found during the life history of lianas.

\section{Materials and methods}

Experimental conditions: The liana studied are native of semideciduous tropical forests of the Southeast of Brazil (48¹2'22”W, 18 57'03”S) (Vargas and Araujo 2014). In these forests, both species occur mainly at edge forests, although juvenile seedlings of $F$. florida are also found in the interior of the forest. When adult, these lianas exhibit tendrils as a way to ascend to the canopy and present fruits that are wind-dispersed (Vargas and Araujo 2014). The climate of this region is classified as Cwa, with a dry season during the winter from April to September and a wet and warm season from October to March (Alvares et al. 2013). The average annual rainfall varies from 1,400 to $1,700 \mathrm{~mm}$ and the maximum temperatures vary between 27 and $30^{\circ} \mathrm{C}$ with a minimum close to $18^{\circ} \mathrm{C}$ (Haridasan and Araújo 2005). Ripe fruits were picked up from at least five individuals before their natural dispersal in September 2012. Afterwards, the fruits were brought to the laboratory, and then were cleaned. Seedlings were obtained from seeds germinated in Petri dishes at $25^{\circ} \mathrm{C}$ under continuous white fluorescent light. Germinated seeds were transplanted to plastic bags (3 1) with a mixture of forest soil and sand in a proportion of $2: 1$. These seedlings were maintained in a nursey for initial establishment. In December 2012, when the seedlings presented the cotyledons and the first pair of expanded leaves, they were taken to an urban fragment of tropical semideciduous forest and randomly distributed into three groups of 15 seedlings: one group was set outside of the forest (full sunlight treatment: FSU), the second beneath the canopy of the forest (shade treatment: $\mathrm{SH}$ ) and the third group consisted of the seedlings that were later transferred from the under canopy to the external forest area (shade-full sunlight treatment: SH-FSU). In this period, ten seedlings were used to determine initial dry mass $\left(\mathrm{t}_{1}\right)$ to compose the data of a relative growth rate. The seedlings were transferred from shade to full sunlight in June 2013 at day 173 and were maintained in these conditions for another $85 \mathrm{~d}$. Until day 173, the seedlings survived under light-limiting conditions presenting around six leaves, indicating some level of shade tolerance in both species. 
The transfer experiment was conducted in June because a period of acclimation to shade and sun conditions was required. The seedlings were kept well-watered during the whole period of the experiment. Therefore, the absence of rains during dry season did not affect the development of the seedlings.

The PPFD ( $\lambda=400-700 \mathrm{~nm})$ was recorded during the experiment under full sunlight and under canopy using a LI-191SA quantum sensor attached to a $L I-250 \mathrm{~A}$ datalogger ( $\mathrm{Li}$-Cor, Inc., Lincoln, NE) on cloudless days near midday. Ten measurements close to the plants, in both conditions, were made. These measurements were also made during the occurrence of sun flecks in the under canopy. The mean values of PPFD and the standard error under full sunlight were $1,397.47 \pm 110.94 \mu \mathrm{mol}$ (photon) $\mathrm{m}^{-2} \mathrm{~s}^{-1}$ with maximum values of $2,185 \mu \mathrm{mol}$ (photon) $\mathrm{m}^{-2} \mathrm{~s}^{-1}$. Under shade conditions, the mean values were 11.24 $\pm 1.48 \mu \mathrm{mol}$ (photon) $\mathrm{m}^{-2} \mathrm{~s}^{-1}$ but due to occurrence of sun flecks in the under canopy the PPFD can reach to $197.87 \pm$ $22.02 \mu$ mol(photon) $\mathrm{m}^{-2} \mathrm{~s}^{-1}$. The air temperature and relative humidity were measured with a thermohygrometer (Instruterm HT-270, China) on different days throughout the experiment. Under full sunlight, the mean values and standard error of air temperature was $29.74 \pm 0.97^{\circ} \mathrm{C}$, while under canopy the air temperature was $24.85 \pm 0.82^{\circ} \mathrm{C}$. The relative humidity was $38.4 \pm 3.20 \%$ and $47.50 \pm 2.88 \%$ under full sunlight and shade, respectively.

Chlorophyll (Chl) fluorescence: The daily courses of Chl fluorescence measurements were made using a pulseamplitude photosynthesis yield analyser (MINI-PAM, Walz, Effeltrich, Germany) equipped with a leaf clip holder (model 2030-B). The maximum fluorescence $\left(\mathrm{F}_{\mathrm{m}}\right)$ and minimum fluorescence $\left(\mathrm{F}_{0}\right)$ were measured after $30 \mathrm{~min}$ of darkening with dark leaf clip (DLC-8, Walz) at predawn. From these data, the potential quantum yield of PSII was calculated as $\left[\mathrm{F}_{\mathrm{v}} / \mathrm{F}_{\mathrm{m}}=\left(\mathrm{F}_{\mathrm{m}}-\mathrm{F}_{0}\right) / \mathrm{F}_{\mathrm{m}}\right]$. The maximum fluorescence $\left(\mathrm{F}_{\mathrm{m}}{ }^{\prime}\right)$ and steady-state fluorescence $(\mathrm{F})$ in the light-adapted state were measured following the methods described by Bilger et al. (1995). Saturated radiation pulses of $700 \mathrm{~ms}$ in duration were applied through a fiber-optic cable that was oriented $60^{\circ}$ to the leaf surface. The angle and distance between the leaf and the fiber-optic cable were manually adjusted and set with the leaf clip holder. During the measurements of light-adapted parameters, care was taken not to shade the leaves with the fiber-optic probe and the leaf clip holder. The effective quantum yield of PSII was calculated as $\left[\Delta \mathrm{F} / \mathrm{F}_{\mathrm{m}}{ }^{\prime}=\left(\mathrm{F}_{\mathrm{m}}{ }^{\prime}-\mathrm{F}\right) / \mathrm{F}_{\mathrm{m}}{ }^{\prime}\right]$ (Genty et al. 1989). The ETR through PSII was calculated as $\mathrm{ETR}=\Delta \mathrm{F} / \mathrm{F}_{\mathrm{m}}{ }^{\prime} \times 0.5 \times \mathrm{PPFD} \times 0.84$ where $\mathrm{PPFD}$ corresponds to the photosynthetic photon flux density radiation incident at the leaf level, which was measured using the microquantum sensor of the leaf clip holder [ $\mu$ mol(photon) $\left.\mathrm{m}^{-2} \mathrm{~s}^{-1}\right], 0.5$ is a multiplication factor that assumes that the transport of a single electron requires the absorption of 2 quanta (White and Critchley 1999), and 0.84 is the photon absorbance at the leaf surface for wavelengths in the range of 400-700 $\mathrm{nm}$. These measurements were made on plants under FSU and SH in April and August 2013 on five plants per treatment.
After this, in order to assess the magnitude of photoinhibition between shade plants after their transfer to full sunlight, the kinetics of $\mathrm{Chl}$ measurements were followed, including $\mathrm{F}_{\mathrm{v}} / \mathrm{F}_{\mathrm{m}}, \mathrm{F}_{0} / \mathrm{F}_{\mathrm{m}}, \Delta \mathrm{F} / \mathrm{F}_{\mathrm{m}}$ ', ETR, and the NPQ, using five plants per treatment. The light intensity during ETR measurements was 1,163.40 $\pm 64.77 \mu \mathrm{mol}$ (photon) $\mathrm{m}^{-2} \mathrm{~s}^{-1}$ under full sunlight and $28.89 \pm 6.63 \mu \mathrm{mol}$ (photon) $\mathrm{m}^{-2} \mathrm{~s}^{-1}$ under shade conditions. The NPQ was calculated as $\left(\mathrm{F}_{\mathrm{m}}-\mathrm{F}_{\mathrm{m}}{ }^{\prime}\right) / \mathrm{F}_{\mathrm{m}}$ ' according to Maxwell and Johnson (2000), using $\mathrm{F}_{\mathrm{m}}$ values at predawn to calculate this quenching parameter. All these measurements were made in totally expanded leaves two nodes below the shoot apex, each from a different plant. Among SH-FSU plants, these Chl fluorescence measurements were made in leaves that expanded under shade conditions, except in C. sceptrum, whose leaves, which had developed in shade, fell right after it was transferred to full sunlight. Although the leaf age was not necessarily the same, the Chl fluorescence measurements were always made on the leaves at the same stage of development. The fluorescence measurements were conducted at 3, 5, 19, 33, 47, 61, and $82 \mathrm{~d}$ after transfer (DAT) during predawn and midday.

Integrations of ETR and averages of NPQ over time were performed for all the treatments. The values of ETR in of $\mu \mathrm{mol}$ (electron) $\mathrm{m}^{-2} \mathrm{~s}^{-1}$ were converted to mol(electron) $\mathrm{m}^{-2} \mathrm{day}^{-1}$, using the sunrise and sunset local times. Then the function $F_{E T R}(t)$ was composed from a linear interpolation of the mean values of ETR data (Press et al. 1992). After, for each species, $F_{E T R}(t)$ was integrated in time as

$$
\mathrm{ETR}_{\text {int }}=\int_{t_{i}}^{t_{f}} \mathrm{~F}_{\mathrm{ETR}}(\mathrm{t}) \mathrm{dt}
$$

where $t_{i}$ is the third day and $t_{f}$ is day 82 . The confidence intervals were also calculated by direct integration in upper and lower time curves. The upper (lower) curve consists of the mean ETR values added (subtracted) to the standard deviation. For the dimensionless NPQ parameter, the average value $\overline{\mathrm{NPQ}}$ was defined by

$$
\overline{\mathrm{NPQ}}=\frac{1}{t_{f}-t_{i}} \int_{t_{i}}^{t_{f}} F_{\mathrm{NPQ}}(t) d t,
$$

where the integral and confidence intervals were solved as described above.

Growth measurements: At the end of the experiment ten plants per treatment were used for growth measurements. The height from the base of the stem to the apex was measured using a millimetre ruler and the number of leaves was registered. The stem diameter was measured at $2 \mathrm{~cm}$ above the soil with a digital calliper. After this, all their leaves were collected, scanned, and the leaf area was determined using the Image J $1.3 v$ software (http://rsb.info. nih.gov/ij/). The plants were separated into leaves, stems plus petioles, and roots. After washing the root system in running water for total removal of the substrate, each part of the seedling was dried at $70^{\circ} \mathrm{C}$ for $48 \mathrm{~h}$ and then weighed. From the primary data of dry mass (DM) and leaf area, the following parameters were derived according to 
Hunt (1982): specific leaf area (SLA - leaf area/leaf DM), leaf area ratio (LAR - leaf area/total plant DM), leaf mass ratio (LMR - leaf dry mass/total plant DM), stem mass ratio $(\mathrm{SMR}-$ stem + petiole $\mathrm{DM} /$ total plant $\mathrm{DM})$ and root mass ratio ( $\mathrm{RMR}$ - root $\mathrm{DM} /$ total plant $\mathrm{DM})$. The RGR was calculated as $R G R=\ln \left(\mathrm{W}_{2}\right)-\ln \left(\mathrm{W}_{1}\right) / \mathrm{t}_{2}-\mathrm{t}_{1}$, where $\mathrm{W}$ corresponds to total plant DM, 1 and 2 are initial and final plant $\mathrm{DM}$, respectively, $\mathrm{t}_{2}-\mathrm{t}_{1}$ correspond to the interval between harvests.

Statistical analysis: The influence of light conditions on Chl fluorescence measurements and growth parameters were evaluated by one-way analysis of variance (oneway ANOVA) followed by Tukey's post-hoc test at 5\% level after checking the normality and homogeneity of variance. When necessary, the natural log transformation was performed to satisfy the assumptions of parametric analysis (Sokal and Rohlf 1981).

\section{Results}

Chl fluorescence: The daily courses of Chl fluorescence carried out during April (2013) showed that predawn values of $\mathrm{F}_{\mathrm{v}} / \mathrm{F}_{\mathrm{m}}$ under FSU were 0.67 and 0.69 for $C$. sceptrum and $F$. florida, respectively (Fig. $1 A, B$ ). In August, under the same conditions, both species exhibited $\mathrm{F}_{\mathrm{v}} / \mathrm{F}_{\mathrm{m}}$ values close to 0.8 during predawn and sunset measurements, with decreases just around midday and afternoon (Fig. 1C,D). The same was not observed in SH plants, where values of $F_{v} / F_{m}$ were high during both periods (Fig. 1). Distinct daily values of $\Delta \mathrm{F} / \mathrm{F}_{\mathrm{m}}$ ' were found among treatments. Low values of $\Delta F / F_{m}$ ' were observed between 11:00 and 13:00 $\mathrm{h}$ for both species under FSU, which were significantly lower compared to SH plants (Fig. 2). Maximum ETR values were reached in August under FSU, whose values were $c a$. $116 \mu \mathrm{mol}\left(\right.$ electron) $\mathrm{m}^{-2} \mathrm{~s}^{-1}$ for both species (Fig. 2G,H).

Reductions of $\mathrm{F}_{\mathrm{v}} / \mathrm{F}_{\mathrm{m}}$ during predawn were found as soon as the seedlings of $C$. sceptrum and F. florida were transferred from shade to full sunlight. In C. sceptrum, the lower values of $F_{v} / F_{m}(0.21)$ were found at 5 DAT and were significantly lower when compared to plants kept continuously under SH and FSU (Fig. $3 A)(F=149.5$, $p<0.0001)$. After the first days of the transfer from shade to full sunlight, the leaves of all individuals of $C$. secptrum fell. However, at 61 DAT, C. sceptrum had new leaves which were completely expanded. These new leaves presented full recovery of $\mathrm{F}_{\mathrm{v}} / \mathrm{F}_{\mathrm{m}}$ values, such as those found for SH and FSU plants (Fig. 3A). F. florida presented the lowest values of $F_{v} / F_{m}(0.42)$ at 3 DAT when compared to $\mathrm{SH}$ and FSU plants with progressively increasing values during the period of acclimation (Fig. $3 C)(F=100.56$, $p<0.0001)$. At 82 DAT, $F$. florida attained similar values of $\mathrm{F}_{\mathrm{v}} / \mathrm{F}_{\mathrm{m}}$ compared to those plants that were found under SH and FSU (Fig. $3 C)(F=1.46, p=0.27)$. At midday, the reduction of $\mathrm{F}_{\mathrm{v}} / \mathrm{F}_{\mathrm{m}}$ values was more pronounced when compared to predawn values for both species under FSU and for SH-FSU (Fig. 3B,D). In addition, significant increases in $\mathrm{F}_{0} / \mathrm{F}_{\mathrm{m}}$ were observed at the first days after transfer in both species during predawn and midday. The higher values were found in C. scpetrum at 5 DAT, but at the end of the experiment the values of $\mathrm{F}_{0} / \mathrm{F}_{\mathrm{m}}$ were lower and close to the plants under FSU conditions (Fig. 3E,F). $F$. florida showed increases in $\mathrm{F}_{0} / \mathrm{F}_{\mathrm{m}}$ ratio at 3 and 5 DAT. Then, the values of $F_{0} / F_{m}$ were continuously decreasing during the experiment with similar values to the plants under FSU after 61 DAT (Fig. 3G,H).

Higher values of $\Delta F / F_{m}$ ' were found in both species under SH conditions. These values varied from 0.65 to 0.72 in C. sceptrum and 0.58 to 0.75 in F. florida (Fig. $4 A, B)$. When these species were transferred from shade to full sunlight, a sharp decline in $\Delta \mathrm{F} / \mathrm{F}_{\mathrm{m}}$ ' was found with values lower than 0.10 at 5 DAT (Fig. $4 A, B$ ). In $F$. florida, increases in $\Delta \mathrm{F} / \mathrm{F}_{\mathrm{m}}$ ' were observed at 19 DAT, whose values were similar to those plants kept under FSU (Fig. 4B). The ETR mean values were between 69.66 and

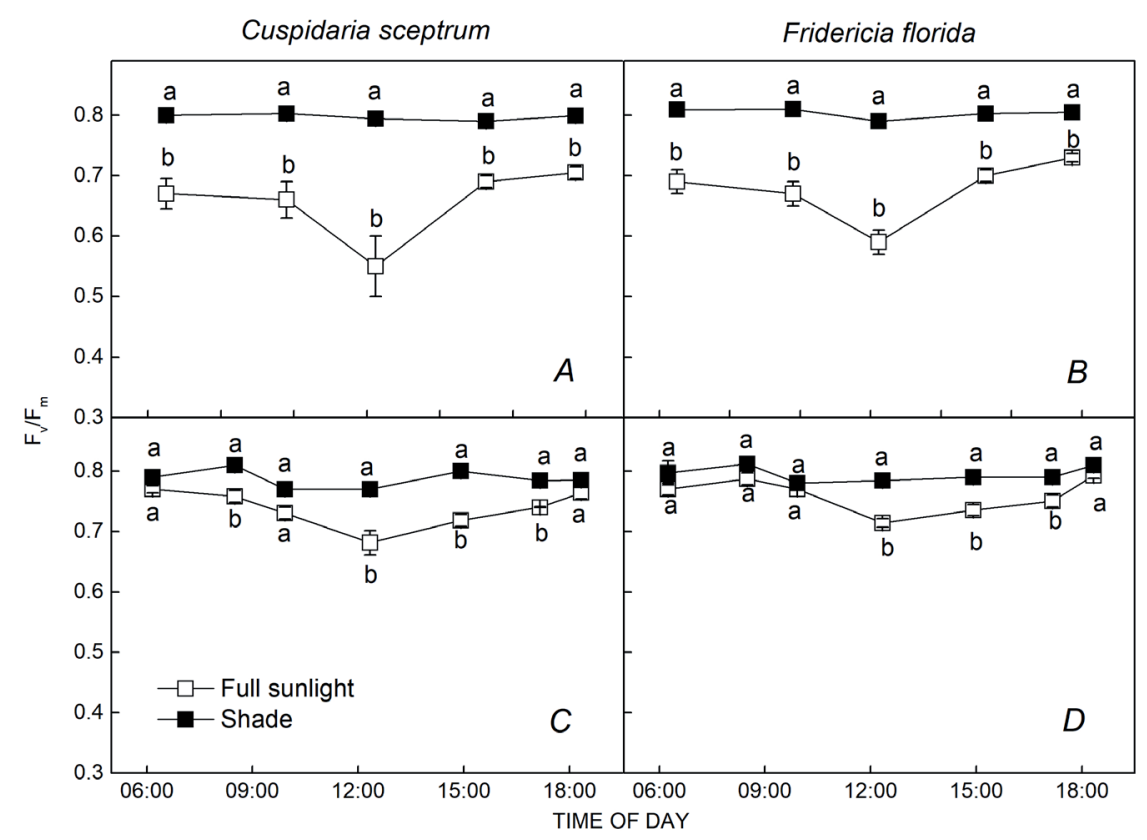

Fig. 1. Daily course of potential quantum yield of PSII $\left(\mathrm{F}_{\mathrm{v}} / \mathrm{F}_{\mathrm{m}}\right)$ in seedlings of Cuspidaria sceptrum $(A, C)$ and Fridericia florida $(B, D)$ under full sunlight (open square) and shade (filled square) during April $2013(A, B)$ and August 2013 (C,D). Data represent the mean $\pm \mathrm{SE}$ in five leaves from different individuals. The values followed by the same letters do not differ according to Tukey's test $(P \leq 0.05)$. 


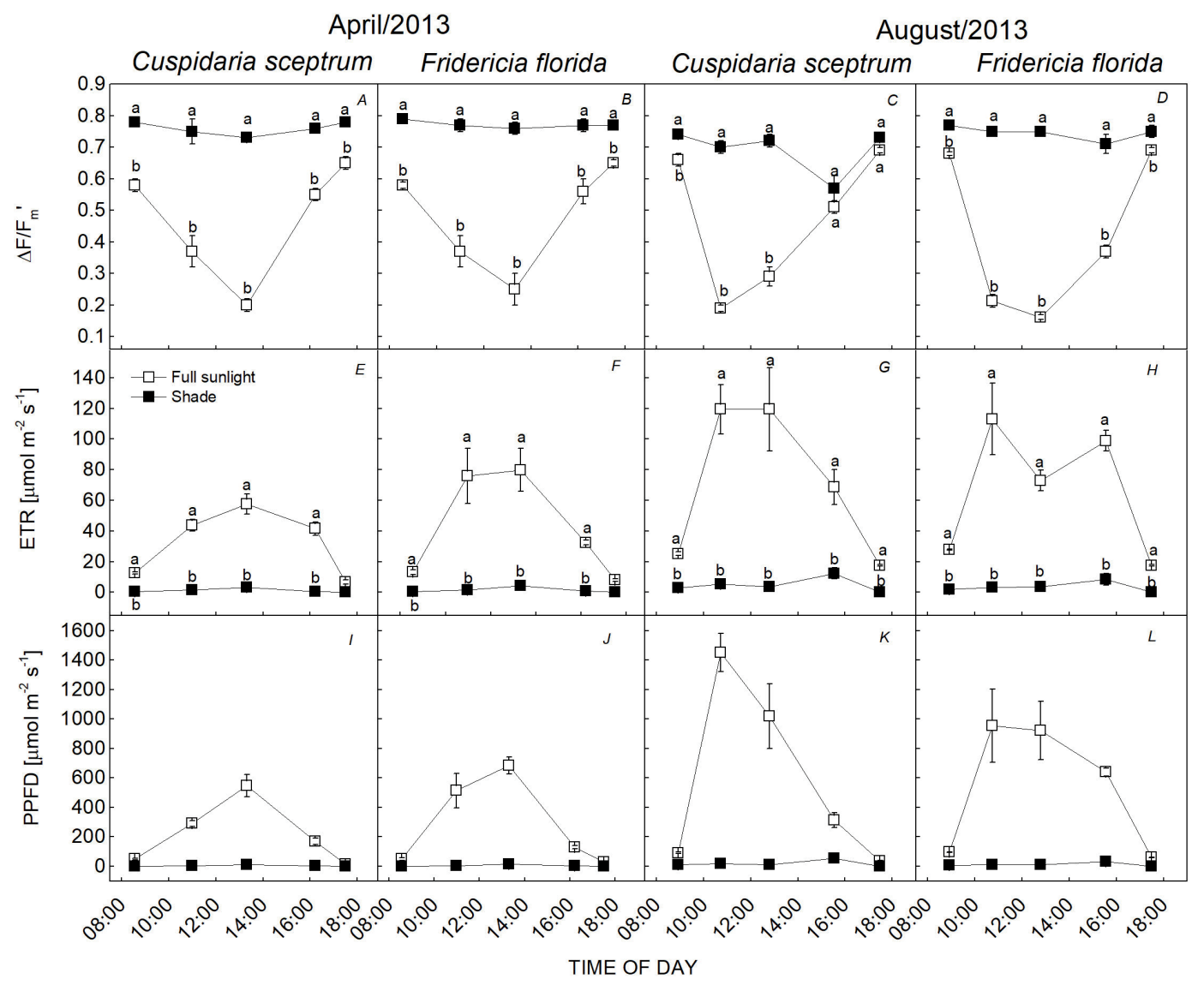

Fig. 2. Daily course of effective quantum yield of PSII $\left(\Delta \mathrm{F} / \mathrm{F}_{\mathrm{m}}{ }^{\prime}\right)(A-D)$, electron transport rate (ETR) $(E-H)$, and PPFD at leaf level $(I-L)$ in seedlings of Cuspidaria sceptrum and Fridericia florida during April $(A, B, E, F)$ and August $2013(C, D, G, H)$. Data represent the mean $\pm \mathrm{SE}$ in five leaves from different individuals. The values followed by the same letters do not differ statistically according to Tukey's test $(P \leq 0.05)$.

163.80 for $C$. sceptrum, and between 72.78 and 133.58 for $F$. florida under FSU (Fig. $4 C, D$ ). When transferred from shade to full sunlight, both species presented marked reduction in ETR on the first DAT. However, at 47 DAT, $F$. florida showed ETR values similar to FSU plants (Fig. 4D). In C. sceptrum, the recovery of ETR values was found at 61 DAT when new leaves were developed (Fig. 4C). At 5 DAT, C. sceptrum showed significant reductions in NPQ compared to plants growing under FSU (Fig. $4 E)(F=13.99, p=0.001)$. At the end of the experiment, FSU and SH-FSU plants exhibited similar values of NPQ (Fig. 4E). Overall, transferred plants of $F$. florida kept values of NPQ similar to FSU plants (Fig. $4 F$ ).

Growth: Both species presented a reduced height under $\mathrm{SH}$. An increase of this parameter was not observed when these plants were transferred from shade to full sunlight. Compared to $\mathrm{SH}$ plants, C. sceptrum increased its leaf numbers when it was transferred to full sunlight, whereas in $F$. florida the total number of leaves did not differ between light treatments (Table 1). In both species, the total leaf area was higher under FSU. When these species were transferred from shade to full sunlight, the total leaf area increased by $34 \%$ in C. sceptrum and by $47 \%$ in $F$. florida when compared to SH plants. Stem diameter and stem DM was higher under FSU in both species. However, the change in light intensity induced increases in stem diameter only in F. florida (Table 1). Pronounced reductions in leaf, root, and total DM were found for both species kept under SH conditions compared to FSU plants. After transfer, both species exhibited increases in leaf, root, and total DM compared to $\mathrm{SH}$ plants, presenting intermediate values when compared to FSU and SH plants (Table 1).

Table 2 shows a comparison of the $\mathrm{ETR}_{\text {int }}$, (Eq. 1), $\overline{\mathrm{NPQ}}$, (Eq. 2), and total DM of each treatment for both species. In the SH-FSU treatment, the $\mathrm{ETR}_{\text {int }}$ values for $F$. florida were higher than that for C. sceptrum, the same occurring for NPQ. Conversely, the total DM was lower for F. florida compared to C. sceptrum.

The biomass partitioning was influenced by light conditions. Under FSU both species allocated less resources to stems $(\mathrm{F}=15.64, p=0.0001$ and $\mathrm{F}=19.51$, $p<0.0001$ for $C$. sceptrum and $F$. florida, respectively) and more to roots $(\mathrm{F}=9.89, p=0.0009$ for $C$. sceptrum and $\mathrm{F}=19.83, p<0.001$ for $F$. florida) (Fig. $5 A, C$ ). LMR was higher under $\mathrm{SH}$ and lower under FSU for $F$. florida, but when these plants were exposed to increased light intensity, no alteration in biomass distribution was found (Fig. 5B). In C. sceptrum, this pattern was not observed. 


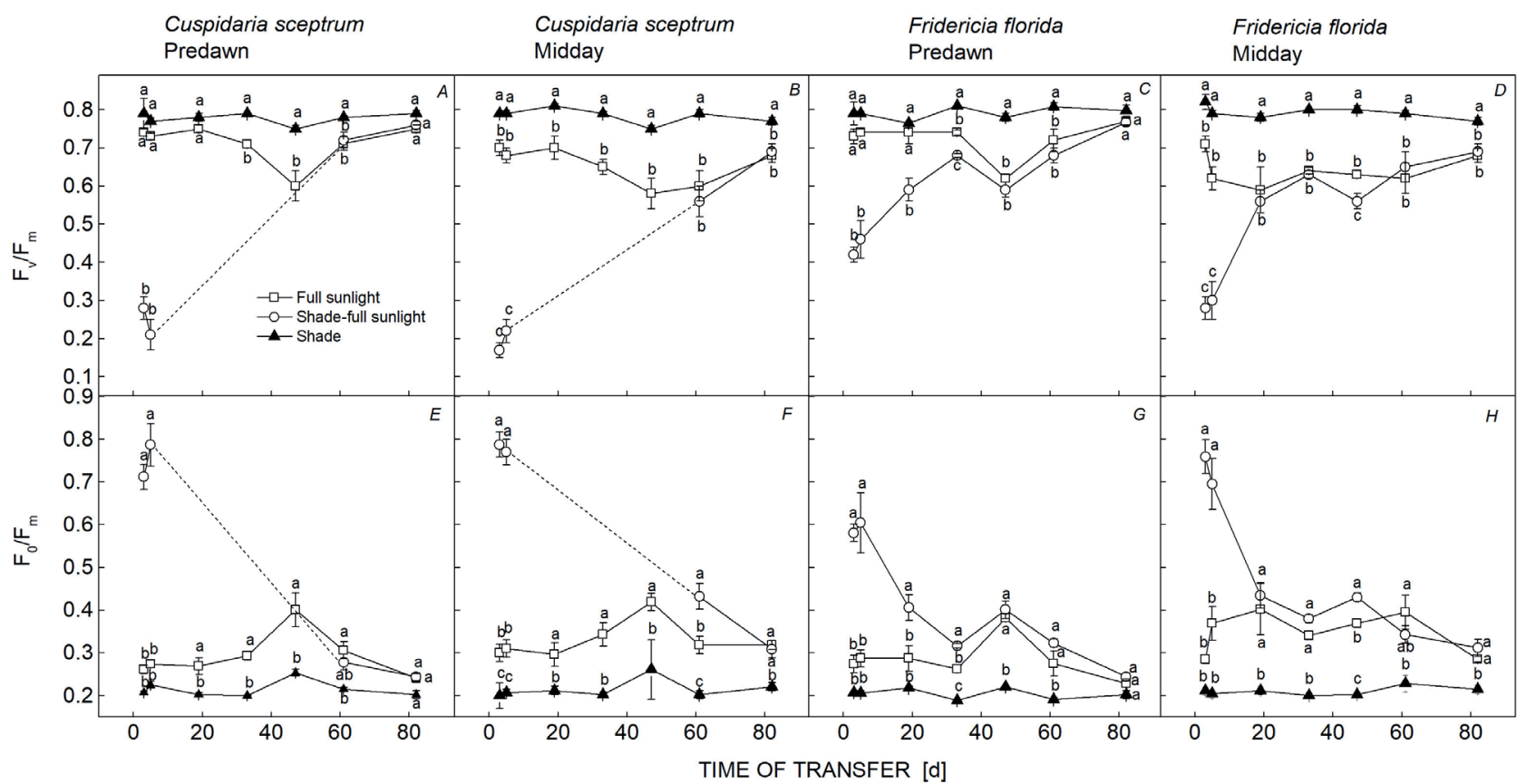

Fig. 3. Changes in the course of time of potential quantum yield of PSII $\left(\mathrm{F}_{\mathrm{v}} / \mathrm{F}_{\mathrm{m}}\right)(A-D)$ and in $\mathrm{F}_{0} / \mathrm{F}_{\mathrm{m}}(E-H)$ in seedlings of Cuspidaria sceptrum and Fridericia florida permanently under full sunlight (open square), transferred from shade to full sunlight (open circle), and permanently under shade (filled triangle), during predawn $(A, E, C, G)$ and midday $(B, F, D, H)$. Data represent the mean $\pm \mathrm{SE}$ in five leaves from different individuals. The values followed by the same letters do not differ statistically according to Tukey's test $(P \leq 0.05)$.

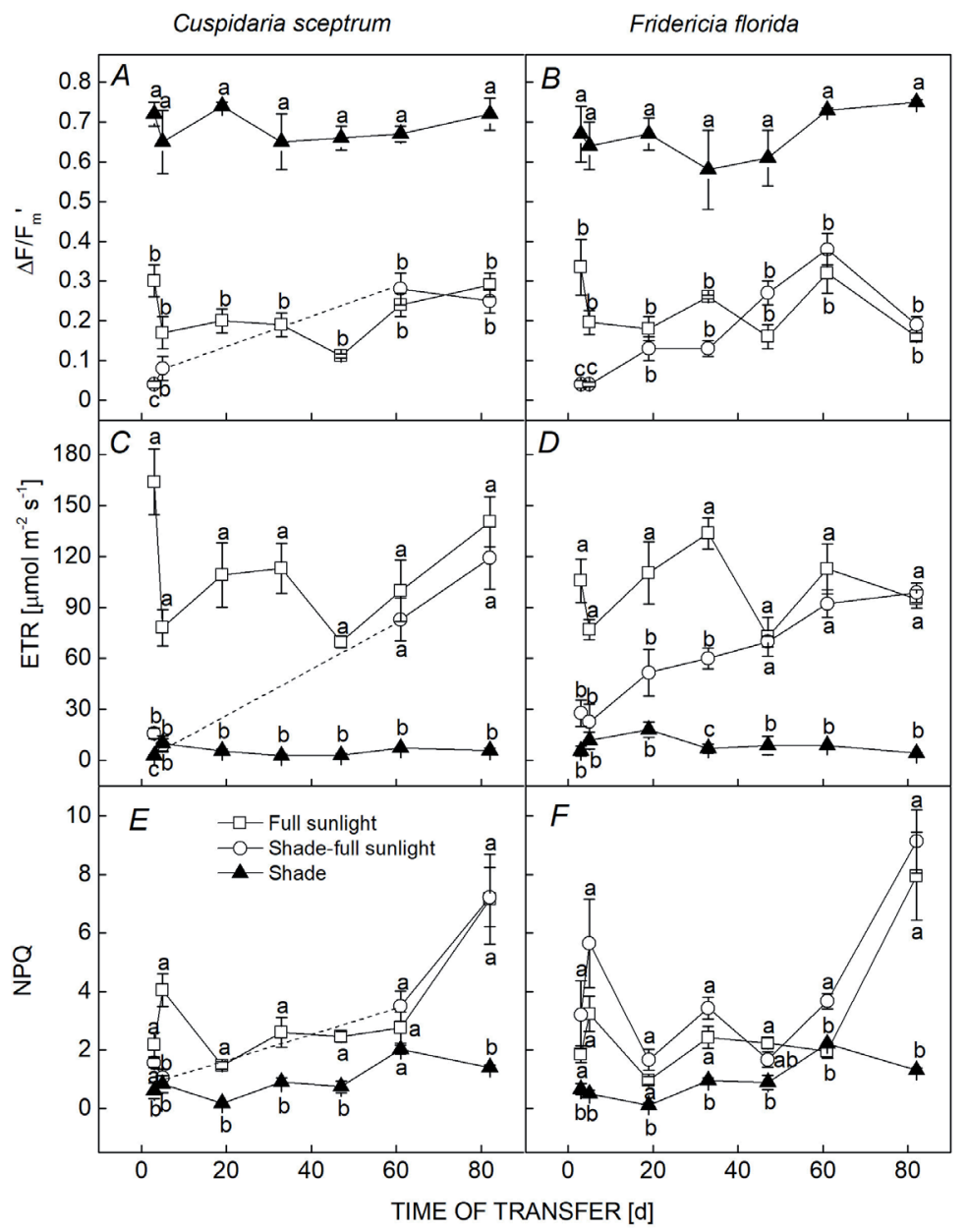

Fig. 4. Changes in the course of time of photosynthetic effective quantum yield of $\operatorname{PSII}\left(\Delta \mathrm{F} / \mathrm{F}_{\mathrm{m}}{ }^{\prime}\right)(A, B)$, electron transport rate $(\mathrm{ETR})(C, D)$, and nonphotochemical quenching (NPQ) $(E, F)$ in seedlings of Cuspidaria sceptrum and Fridericia florida permanently under full sunlight (open square), transferred from shade to full sunlight (open circle), and permanently under shade (filled triangle square). Data represent the mean \pm SE in five leaves from different individuals. The values followed by the same letters do not differ statistically according to Tukey's test $(P \leq 0.05)$ 
Table 1. Height, leaf number, stem diameter, total leaf area, dry mass of stem, leaves and roots, and total biomass of Cuspidaria sceptrum and Fridericia florida. The data represent mean \pm SE. In each line, values followed by the same letters do not differ according to Tukey's test $(P \leq 0.05) . \mathrm{F}(p)=\mathrm{F}$ values and their probabilities $(p)$ are results from ANOVA.

\begin{tabular}{|c|c|c|c|c|c|c|c|c|}
\hline \multirow[b]{2}{*}{ Growth parameters } & \multicolumn{4}{|c|}{ Cuspidaria spectrum } & \multicolumn{4}{|c|}{ Fridericia florida } \\
\hline & Full sunlight & $\begin{array}{l}\text { Shade-full } \\
\text { sunlight }\end{array}$ & Shade & $\mathrm{F}(p)$ & Full sunlight & $\begin{array}{l}\text { Shade-full } \\
\text { sunlight }\end{array}$ & Shade & $\mathrm{F}(p)$ \\
\hline Height $[\mathrm{cm}]$ & $17.35 \pm 0.69^{\mathrm{a}}$ & $12.40 \pm 0.82^{b}$ & $11.95 \pm 1.01^{\mathrm{b}}$ & $\begin{array}{l}12.42 \\
(0.0003)\end{array}$ & $6.73 \pm 0.38^{a}$ & $5.65 \pm 0.35^{\mathrm{ab}}$ & $5.50 \pm 0.20^{\mathrm{b}}$ & $\begin{array}{l}4.15 \\
(0.002)\end{array}$ \\
\hline Total leaf numbers & $34.50 \pm 2.93^{\mathrm{a}}$ & $19.2 \pm 1.37^{\mathrm{b}}$ & $6.30 \pm 0.54^{c}$ & $\begin{array}{l}55.69 \\
(<0.0001)\end{array}$ & $11.4 \pm 0.62^{\mathrm{a}}$ & $10.0 \pm 1.01^{\mathrm{a}}$ & $9.10 \pm 0.74^{\mathrm{a}}$ & $\begin{array}{l}2.07 \\
(0.144)\end{array}$ \\
\hline Total leaf area $\left[\mathrm{cm}^{2}\right]$ & $97.86 \pm 10.63^{a}$ & $33.02 \pm 8.04^{\mathrm{b}}$ & $11.35 \pm 1.55^{\mathrm{c}}$ & $\begin{array}{l}33.79 \\
(<0.0001)\end{array}$ & $55.69 \pm 6.21^{\mathrm{a}}$ & $35.48 \pm 6.56^{\mathrm{b}}$ & $16.81 \pm 1.34^{\mathrm{c}}$ & $\begin{array}{l}13.61 \\
(0.0002)\end{array}$ \\
\hline Stem diameter $[\mathrm{m}]$ & $2.55 \pm 0.19^{\mathrm{a}}$ & $1.80 \pm 0.08^{\mathrm{b}}$ & $1.51 \pm 0.05^{\mathrm{b}}$ & $\begin{array}{l}18.39 \\
(<0.0001)\end{array}$ & $2.22 \pm 0.13^{\mathrm{a}}$ & $1.76 \pm 0.07^{\mathrm{b}}$ & $1.32 \pm 0.08^{c}$ & $\begin{array}{l}21.44 \\
(<0.0001)\end{array}$ \\
\hline Stem dry mass $[\mathrm{g}]$ & $0.63 \pm 0.10^{\mathrm{a}}$ & $0.13 \pm 0.02^{b}$ & $0.06 \pm 0.004^{c}$ & $\begin{array}{l}80.44 \\
(<0.0001)\end{array}$ & $0.16 \pm 0.02^{\mathrm{a}}$ & $0.05 \pm 0.006^{\mathrm{b}}$ & $0.03 \pm 0.003^{\mathrm{b}}$ & $\begin{array}{l}25.65 \\
(<0.0001)\end{array}$ \\
\hline Leaf dry mass [g] & $0.62 \pm 0.10^{\mathrm{a}}$ & $0.20 \pm 0.04^{\mathrm{b}}$ & $0.02 \pm 0.003^{\mathrm{c}}$ & $\begin{array}{l}56.78 \\
(<0.0001)\end{array}$ & $0.44 \pm 0.004^{\mathrm{a}}$ & $0.22 \pm 0.03^{b}$ & $0.06 \pm 0.005^{\mathrm{c}}$ & $\begin{array}{l}41.25 \\
(<0.0001)\end{array}$ \\
\hline Root dry mass [g] & $2.61 \pm 0.30^{\mathrm{a}}$ & $0.32 \pm 0.06^{b}$ & $0.10 \pm 0.001^{\mathrm{c}}$ & $\begin{array}{l}115.89 \\
(<0.0001)\end{array}$ & $0.76 \pm 0.007^{\mathrm{a}}$ & $0.14 \pm 0.03^{b}$ & $0.05 \pm 0.006^{\mathrm{c}}$ & $\begin{array}{l}92.28 \\
(<0.0001)\end{array}$ \\
\hline Total dry mass $[\mathrm{g}]$ & $3.88 \pm 0.38^{\mathrm{a}}$ & $0.65 \pm 0.12^{\mathrm{b}}$ & $0.22 \pm 0.03^{\mathrm{c}}$ & $\begin{array}{l}116.53 \\
(<0.0001)\end{array}$ & $1.37 \pm 0.10^{\mathrm{a}}$ & $0.42 \pm 0.05^{\mathrm{b}}$ & $0.15 \pm 0.01^{\mathrm{c}}$ & $\begin{array}{l}98.47 \\
(<0.0001)\end{array}$ \\
\hline
\end{tabular}

Table 2. ETR integrated over time $\left[\mathrm{ETR}_{i n t}\right], \overline{\mathrm{NPQ}}$ over the experiment time after transfer, and total dry mass [TDM] in seedlings of Cuspidaria sceptrum and Fridericia florida under full sunlight, under shade, and transferred from shade to full sunlight.

\begin{tabular}{lcccccc}
\hline & \multicolumn{2}{l}{ Cuspidaria sceptrum } & \multicolumn{3}{l}{ Fridericia florida } \\
& Full sunlight & $\begin{array}{l}\text { Shade-full } \\
\text { sunlight }\end{array}$ & Shade & Full sunlight & $\begin{array}{l}\text { Shade-full } \\
\text { sunlight }\end{array}$ & Shade \\
\hline $\mathrm{ETR}_{\text {int }}\left[\mathrm{mol} \mathrm{m}^{-2}\right]$ & $321 \pm 43$ & $110 \pm 18$ & $17 \pm 4$ & $323 \pm 37$ & $215 \pm 25$ & $31 \pm 9$ \\
$\mathrm{NPQ}$ & $3.15 \pm 0.53$ & $1.86 \pm 0.28$ & $1.05 \pm 0.14$ & $2.84 \pm 0.46$ & $3.84 \pm 0.56$ & $1.07 \pm 0.11$ \\
$\mathrm{TDM}[\mathrm{g}]$ & $3.88 \pm 0.38$ & $0.65 \pm 0.12$ & $0.22 \pm 0.03$ & $1.37 \pm 0.10$ & $0.42 \pm 0.05$ & $0.15 \pm 0.01$ \\
\hline
\end{tabular}

Increases in SLA were found for both species under SH conditions (Fig. 5D). When transferred from shade to full sunlight, both species were capable to produce leaves with lower SLA compared to SH plants, with similar values of FSU plants $(\mathrm{F}=81.75, p=0.0001$ and $\mathrm{F}=57.6$, $p<0.0001$ for $C$. sceptrum and $F$. florida, respectively) (Fig. 5D). LAR values were twice as high for $F$. florida under $\mathrm{SH}$ in comparison to FSU plants $(\mathrm{F}=25.36, p<0.0001)$ (Fig. 5E). After transfer, F. florida presented reductions in LAR, with intermediate values compared to FSU and SH plants (Fig. 5E). C. sceptrum did not show significant differences for LAR between SH and SH-FSU plants, but for FSU, LAR was significantly lower $(\mathrm{F}=6.13$, $p=0.006$ ) (Fig. 5E). The RGR was higher under FSU and lower under $\mathrm{SH}$ for both species (Fig. $5 F$ ). In addition, both species exhibited increases in RGR when transferred from shade to full sunlight, but these values were lower than that for FSU plants $(\mathrm{F}=136.9, p<0.0001, \mathrm{~F}=106.8$, $p<0.0001$ for $C$. sceptrum and $F$. florida, respectively) (Fig. $5 F$ ).

\section{Discussion}

Both lianas of the present study are frequently found in edge forests, where conditions of high light intensity prevail. Even so, our data showed that these lianas underwent photoinhibition under full sunlight, since predawn and midday values of $F_{v} / F_{m}$ were below 0.8 (Lüttge 2008). These values of $F_{v} / F_{m}$ were significantly lower than those for shade plants during the day in April. During the second daily course in August, both species presented reductions on $\mathrm{F}_{\mathrm{v}} / \mathrm{F}_{\mathrm{m}}$ close to midday and in the afternoon with a recovery during predawn and sunset, which suggests dynamic photoinhibition (Zhou et al. 2016). These results pointed to leaf adjustments to full sunlight over time, since photoinhibition was less severe for both species in August. It is probable that some protective mechanisms to deal with high light intensity were operating in these leaves (Franco and Lüttge 2002). The reductions in effective quantum yield $\left(\Delta \mathrm{F} / \mathrm{F}_{\mathrm{m}}{ }^{\prime}\right), 0.16$ for $C$. sceptrum and 0.29 for F. florida (Fig. 2C,D) FSU plants, indicate that only a low fraction of light absorbed by $\mathrm{Chl}$ associated with 


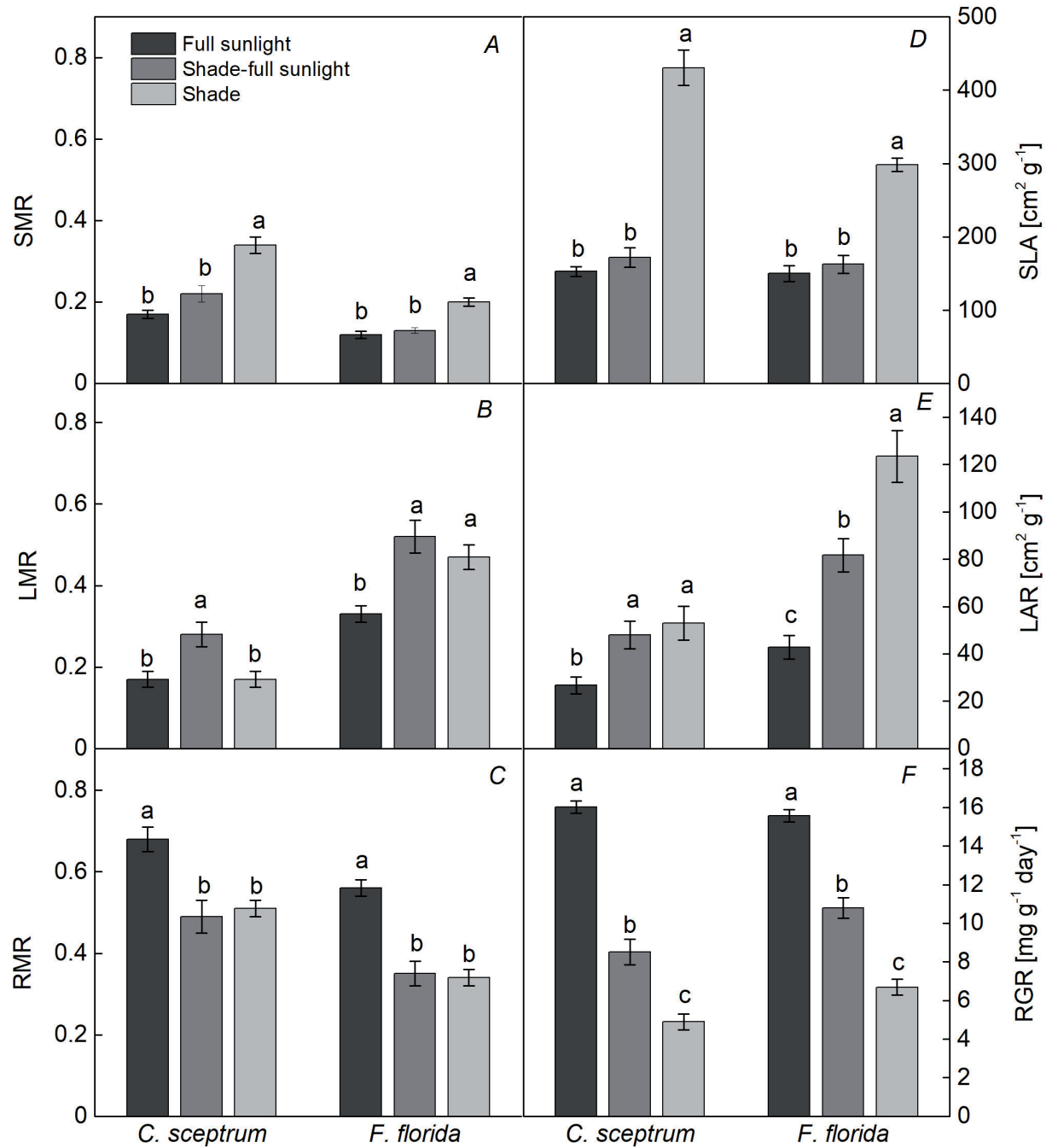

Fig. 5. Mean values of stem mass ratio $(\mathrm{SMR})(A)$, leaf mass ratio (LMR) $(B)$, root mass ratio (RMR) $(C)$, specific leaf area (SLA) $(D)$, leaf area ratio $(\mathrm{LAR})(E)$, and relative growth rate $(\mathrm{RGR})(F)$ in seedlings of Cuspidaria sceptrum and Fridericia florida permanently under full sunlight (dark gray), transferred from shade to full sunlight (gray), and permanently under shade (light gray). Data represent the mean $\pm \mathrm{SE}$ in ten plants of different light treatments. The values followed by the same letters do not differ statistically according to Tukey's test $(P \leq 0.05)$.
PSII was used for photochemistry (Maxwell and Johnson 2000). Simultaneously, ETR maintained high values, over $100 \mu \mathrm{mol} \mathrm{m} \mathrm{m}^{-2} \mathrm{~s}^{-1}$ in both species between 10:00 and 15:00 h (Fig. 2G,H). These ETR values are within those found in Canavalia parviflora, a liana from semideciduous tropical forests of Brazil, and Bridelia stipularis, a liana from the savanna vegetation of Southwest China (Sanches and Válio 2008, Zhang et al. 2016), and may reflect a shift of electron flow to another process not directly involved in carbon assimilation, such as photorespiration (Franco and Lüttge 2002, Zhang et al. 2016).

Photoinhibition occurs when the light intensity, which reaches the leaf surface, greatly exceeds leaf capacity to use it in photosynthesis and/or in thermal dissipation (Takahashi and Murata 2008). This disbalance may be intensified mainly when shade plants are transferred to full sunlight, a common condition found when a gap is created within the forest (Valladares et al. 2002, Azevedo and Marenco 2012). Both liana species showed reductions in $\mathrm{F}_{\mathrm{v}} / \mathrm{F}_{\mathrm{m}}$ on the first days of transfer from shade to full sunlight, especially $C$. sceptrum. This species exhibited strong photoinhibition at 5 DAT, with a sharp decline in $F_{v} / F_{m}$ compared to SH and FSU plants. This abrupt drop in $\mathrm{F}_{\mathrm{v}} / \mathrm{F}_{\mathrm{m}}$ led to the formation of necrosis in leaves developed under shade conditions. Between 6 and 8 DAT, all individuals of $C$. sceptrum, which had been transferred from shade to full sunlight, lost their leaves. This result indicates that, at least in the first days, the sudden exposure of shade leaves to full sunlight with concomitant increases in air temperature contributed to the occurrence of photodamage (Lüttge 2008). Furthermore, the higher values of SLA, i.e., the production of thinner leaves, as found in C. sceptrum under shade, probably had an influence on the marked reduction of $F_{v} / F_{m}$ on the first days of transfer. Higher SLA values can lead to higher absorption efficiency under shade (Sanches and Válio 2006), but when these thinner leaves are suddenly exposed to full sunlight, photoinhibition could be exacerbated. Similar findings were found by Tobita et al. (2010), where the leaves of Sasa senanensis with higher LMA (the opposite of SLA) were less susceptible to photoinhibition after increases in irradiance than that of Quercus mongolica and Acer mono. Although C. sceptrum lost its leaves shortly after its transfer, new leaves were produced under full sunlight. The formation of leaf primordia was already observed at 10 DAT. After 60 DAT, these leaves had completed their expansion. These newly formed leaves showed full recovery of photoinhibition, since $\mathrm{F}_{\mathrm{v}} / \mathrm{F}_{\mathrm{m}}$ was close the values found in $\mathrm{SH}$ and FSU plants. 
In $F$. florida, the drop of $47 \%$ of $\mathrm{F}_{\mathrm{v}} / \mathrm{F}_{\mathrm{m}}$, measured at 3 DAT, was not so sharp when compared to C. sceptrum indicating that photoinhibition was less severe in this species. The $F_{v} / F_{m}$ values of 0.42 to 0.59 at predawn at 3 and 5 DAT, pointed to chronic photoinhibition in F. florida due to the absence of recovery in $\mathrm{F}_{\mathrm{v}} / \mathrm{F}_{\mathrm{m}}$ overnight (Lüttge 2008, Azevedo and Marenco 2012). Hence, both species showed a dysfunction of PSII that led to reductions in $\mathrm{F}_{\mathrm{v}} / \mathrm{F}_{\mathrm{m}}$ when transferred from shade to full sunlight. Also, in both species, the ratio $F_{0} / F_{m}$ increased markedly just after the first days after transfer, indicating that they underwent stress when transferred from shade to full sunlight (Roháček 2002). In $F$. florida, the increases in $\mathrm{F}_{0} / \mathrm{F}_{\mathrm{m}}$ occurred due to lowering $\mathrm{F}_{\mathrm{m}}$, which is often related to non-radiative energy dissipation (Dias and Marenco 2006). Likewise, in $C$. sceptrum, the rise in $\mathrm{F}_{0} / \mathrm{F}_{\mathrm{m}}$ was due to reductions of $\mathrm{F}_{\mathrm{m}}$. However, this species exhibited necrosis in their leaves after sudden exposition to full sunlight, suggesting that energy dissipation was not efficient enough to protect PSII reaction centres. During midday, the increase in $\mathrm{F}_{0} / \mathrm{F}_{\mathrm{m}}$ was caused by the increase in $\mathrm{F}_{0}$, which could explain the occurrence of photodamage in this species (Krause 1988).

The drop of $\Delta \mathrm{F} / \mathrm{F}_{\mathrm{m}}$ ' as well as ETR values on the first days of transfer reinforces the occurrence of photoinhibition in both liana species (Kitao et al. 2006). However, $F$. florida was able to gradually increase $\mathrm{F}_{\mathrm{v}} / \mathrm{F}_{\mathrm{m}}$ over time, with a complete recovery of the potential quantum yield of PSII at 82 DAT. It is important to emphasize that, contrary to $C$. sceptrum, the response of $F$. florida to increases in light intensity was achieved by adjustments in leaves previously developed under shade conditions, which suggests that mechanisms of nonphotochemical quenching were possibly operating in this species under full sunlight conditions (Guo et al. 2006). Indeed, transferred plants of $F$. florida were able to maintain the NPQ values close to those of FSU plants, whereas for C. sceptrum, the NPQ values were significantly lower at 5 DAT (Fig. $4 E, F$ ).

Considering the whole-plant acclimation, both species presented increases in leaf area and reductions in SLA and in SMR when they were transferred from shade to full sunlight. C. sceptrum produced higher leaf numbers, whereas in F. florida, leaf production was kept constant. This result points out to a more conservative response in $F$. florida compared to that of $C$. sceptrum. Although the leaf number was not changed among light treatments in $F$. florida, the total leaf area was larger at full sunlight than that at SH-FSU and the lowest at SH. These results mean that the leaf area of each leaf enlarged as the light intensity increased. Moreover, increases in stem, leaf, and root DM were achieved when these plants were exposed to full sunlight. It is important to mention that the increase in root DM in C. sceptrum and F. florida was about 69 and $64 \%$, respectively, when compared to $\mathrm{SH}$ plants. This could explain the full physiological recovery found at the leaf level, as indicated by high values of $F_{v} / F_{m}$ and ETR at the end of the experiment. Increases in root growth were able to meet the higher water demand as the alterations in growth conditions were followed by rises in air temperature and decreases in relative humidity. In C. sceptrum, the RMR was close to 0.50 , as found in
SH-FSU plants, which could contribute to the production of new leaves under full sunlight, since the roots may function as carbohydrate storage for the period of absence of leaves.

Although both species increased their growth when exposed to higher levels of light, the full acclimation at whole-plant level was only partially reached, as the total dry mass and RGR was lower in SH-FSU plants than that in FSU plants. The integration of ETR over time shows that although $F$. florida had higher values of ETR compared to C. sceptrum, the light available for photochemical reactions was not so efficiently converted into biomass at the end of the experiment compared to FSU plants (Table 2). This can be found from the NPQ values (Fig. 4). In the first days after the transfer, when both species experienced more severe photoinhibition, $F$. florida was able to maintain NPQ values similar to those of FSU plants, whereas in transferred plants of C. sceptrum, NPQ values were lower. NPQ is associated with energy dissipation as heat and is considered a protection mechanism against excess light (Guo et al. 2006, Rabelo et al. 2013). Hence, it is probable that the energy used to recover from initial photoinhibition and resume PSII activity was higher than the energy used to promote growth, especially in F. florida. In C. sceptrum, the lower values of $\overline{\mathrm{NPQ}}$ may be an indicative of insufficient protection of PSII after the sudden increase in light intensity after transfer (Table 2). As a consequence, the leaves fell. In addition, the reduced growth in shade probably had a role in whole-plant acclimation. As pointed by Avalos and Mulkey (2014), a small seedling with little leaf area and root dry mass, as found in C. sceptrum and $F$. florida under shade, could limit the capacity of these species to increase resource acquisition under new light conditions. This pattern was not found in Cedrela fissilis, a tree species that showed complete recovery of total biomass when transferred from shade to full sunlight (Sanches et al. 2017). Although it is often assumed that lianas are light-demanding species (Dewalt et al. 2010), at least in the initial life stage, the relative growth and total biomass accumulation values are close to those found in late-successional tree species and lower than those found for pioneer tree species (Souza and Válio 2003, Feijó et al. 2009). These results show that lianas may share some life traits that are common with shade-tolerant tree species, while both groups are in the juvenile stage and lianas are still self-supporting plants, as in our experiment.

Finally, both liana species presented some traits that allow them to cope with contrasting light conditions. Under low light, increases of SLA and LAR, which favour light interception and carbon gain, were found. Whereas under full sunlight, opposite responses were observed, with reductions of SLA and LAR, and increases in RMR, that contribute to avoid light and water stress (Souza and Válio 2003, Paulilo et al. 2007, Feijó et al. 2009). However, when alterations in light conditions were imposed, distinct responses emerged. As a whole, the potential acclimation found in F. florida was achieved by physiological adjustments at leaf level, while $C$. sceptrum exhibited a morphological response, changing all older leaves for new ones under the new light conditions. The 
initial photoinhibition found during increases in light conditions impacted the growth of these two liana species, although they are frequently found in forest edges and have a heliophyte character when adult plants.

\section{References}

Anbarashan M., Parthasarathy N.: Diversity and ecology of lianas in tropical dry evergreen forests on the Coromandel Coast of India under various disturbance regimes. - Flora 208: 22-32, 2013.

Alvares C.A., Stape J.L., Sentelhas P.C et al.: Köppen's climate classification map for Brazil. - Meteorol Z. 22: 711-728, 2013.

Avalos G., Mulkey S.S.: Photosynthetic and morphological acclimation of seedlings of tropical lianas to changes in the light environment. - Am. J. Bot. 101: 2088-2096, 2014.

Azevedo G.F.C., Marenco R.A.: Growth and physiological changes in saplings of Minquartia guianensis and Swietenia macrophylla during acclimation to full sunlight. Photosynthetica 50: 86-94, 2012.

Bazzaz F.A.: The physiological ecology of plant succession. Annu. Rev. Ecol. Syst. 10: 351-371, 1979.

Bilger W., Schreiber U., Bock M.: Determination of the quantum efficiency of photosystem II and of non-photochemical quenching of chlorophyll fluorescence in the field. - Oecologia 102: 425-432, 1995.

Cai Z.Q., Bongers F.: Contrasting nitrogen and phosphorus resorption efficiencies in trees and lianas from a tropical montane rain forest in Xishuangbanna, south-west China. - J. Trop. Ecol. 23: 115-118, 2007.

Cai Z.Q., Poorter L., Cao K.F. et al.: Seedling growth strategies in Bauhinia species: Comparing lianas and trees. - Ann. Bot.London 100: 831-838, 2007.

Cai Z.Q., Schnitzer S.A., Bongers F.: Seasonal differences in leaf-level physiology give lianas a competitive advantage over trees in a tropical seasonal forest. - Oecologia 161: 2533, 2009

Celis G., Avalos G.: Acclimation of seedlings of Gnetum leybolddii Tul. (Gnetaceae) to light changes in a tropical rain forest. - Rev. Biol. Trop. 61: 1859-1868, 2013.

Dewalt S.J., Schnitzer S.A., Denslow J.S.: Density and diversity of lianas along a chronosequence in a central Panamanian lowland forest. - J. Trop. Ecol. 16: 1-19, 2000.

Dias D.P., Marenco R.A.: Photoinhibition of photosynthesis in Minquartia guianensis and Swietenia macrophylla inferred by monitoring the initial fluorescence. - Photosynthetica 44 : 235-240, 2006.

dos Anjos L.D., Oliva M.A., Kuki K.N.: Fluorescence imaging of light acclimation of Brazilian Atlantic forest tree species. Photosynthetica 50: 95-108, 2012.

Einhorn K.S., Rosenqvist E., Leverenz J.W.: Photoinhibition in seedlings of Fraxinus and Fagus under natural light conditions: implications for forest regeneration? - Oecologia 140: 241-251, 2004

Feijó N.S.A., Mielke M.S., Gomes F.P. et al.: Growth and photosynthetic responses of Gallesia integrifolia (Spreng.) Harms and Schinus terebinthifolius Raddi seedlings in dense shade. - Agroforest. Syst. 77: 49-58, 2009.

Franco A.C., Lüttge U.: Midday depression in savanna trees: coordinated adjustments in photochemical efficiency, photorespiration, $\mathrm{CO}_{2}$ assimilation and water use efficiency. - Oecologia 131: 356-365, 2002.

Genty B., Briantais J.M., Baker N.R.: The relationship between the quantum yield of photosynthetic electron transport and quenching of chlorophyll fluorescence. - Biochim. Biophys. Acta 990: 87-92, 1989.

Gentry, A.H.: The distribution and evolution of climbing plants. - In: Putz F.E., Mooney H.A. (ed.): The Biology of Vines. Pp. 3-49. Cambridge University Press, Cambridge 1991.

Guo X.R., Cao K.F., Xu Z.F.: Acclimation to irradiance in seedlings of three tropical rain forest Garcinia species after simulated gap formation. - Photosynthetica 44: 193-201, 2006.

Haridasan M., Araújo G.M.: [Nutritional status of woody species of two semideciduous forests in Uberlândia, MG] - Rev. Bras. Bot. 28: 295-303, 2005. [In Portuguese]

Holbrook N.M., Putz F.E.: Physiology of tropical vines and hemiepiphytes: Plants that climb up and plants that climb down. - In: Mulkey S.S., Chazdon R.L., Smith A.P. (ed.): Tropical Forest Plant Ecophysiology. Pp. 363-395. Chapman and Hall, New York 1996.

Hunt R.: Plant Growth Curves. The Functional Approach to Growth Analysis. Pp. 248. Edward Arnold, London 1982.

Kitao M., Yoneda R., Tobita H. et al.: Susceptibility to photoinhibition in seedlings of six tropical fruit tree species native to Malaysia following transplantation to a degraded land. - Trees 20: 601-610, 2006.

Krause G.H.: Photoinhibition of photosynthesis. An evaluation of damaging and protective mechanisms. - Physiol. Plantarum 74: 566-574, 1988.

Krause G.H., Koroleva O.Y., Dalling J.W. et al.: Acclimation of tropical tree seedlings to excessive light in simulated tree-fall gaps. - Plant Cell. Environ. 24: 1345-1352, 2001.

Krause G.H., Winter K., Matsubara S. et al.: Photosynthesis, photoprotection, and growth of shade-tolerant tropical tree seedlings under full sunlight. - Photosynth. Res. 113: 273285, 2012.

Lavinsky A.O., Gomes F.P., Mielke M.S. et al.: Photosynthetic acclimation in shade-developed leaves of Euterpe edulis Mart (Arecaceae) after long-term exposure to high light. Photosynthetica 52: 351-357, 2014.

Lee D.W., Richards J.H.: Heteroblastic development in vines. In: Putz F.E., Mooney H.A. (ed.): The Biology of Vines. Pp. 205-243. Cambridge University Press, Cambridge 1991.

Lestari D.P., Nichols D.: Seedlings of subtropical rainforest species from similar successional guild show different photosynthetic and morphological responses to varying light levels. - Tree Physiol. 37: 186-198, 2017.

Letcher S.G., Chazdon R.L.: Life history traits of lianas during tropical forest succession. - Biotropica 44: 720-727, 2012.

Lohmann L.G., Taylor C.M.: A new generic classification of tribe Bignonieae (Bignoniaceae). - Ann. Mo. Bot. Gard. 99: 348$489,2014$.

Lovelock C.E., Jebb M., Osmond C.B.: Photoinhibition and recovery in tropical plant species: response to disturbance. Oecologia 97: 297-307, 1994.

Lüttge U.: Physiological Ecology of Tropical Plants. Pp. 458. Springer-Verlag, Berlin 2008.

Martínez-Izquierdo L., García M.M., Powers J.S. et al.: Lianas suppress seedling growth and survival of 14 tree species in a Panamanian tropical forest. - Ecology 97: 215-224, 2016.

Mazzanatti T., Calzavara A.K., Pimenta J.A. et. al.: Light acclimation in nursery: morphoanatomy and ecophysiology of seedlings of three light-demanding neotropical tree species. - Braz. J. Bot. 39: 19-28, 2016.

Maxwell K., Johnson G.N.: Chlorophyll fluorescence - a practical guide. - J. Exp. Bot. 51: 659-668, 2000.

Morellato L.P.C, Leitão-Filho H.F.: Reproductive phenology of climbers in a Southeastern Brazilian forest. - Biotropica 28: 180-191, 1996. 
Naidu S.L., DeLucia E.H.: Growth, allocation and water relations of shade-grown Quercus rubra L. saplings exposed to a lateseason canopy gap. - Ann. Bot.-London 80: 335-344, 1997.

Naidu S.L., DeLucia E.H.: Physiological and morphological acclimation of shade-grown tree seedlings to late-season canopy gap formation. - Plant. Ecol. 138: 27-40, 1998.

Naramoto M., Katahata S., Mukai Y. et al.: Photosynthetic acclimation and photoinhibition on exposure to high light in shade-developed leaves of Fagus crenata seedlings. - Flora 201: 120-126, 2006.

Nascimento A.R.T., Araújo G.M., Giroldo A.B. et al.: Gap area and tree community regeneration in a tropical semideciduous forest. - In: Sudarshana P., Nageswara-Rao M., Soneji J.R. (ed.): Tropical Forests. Pp. 139-154. Intech Open Access Publishers, Rijeka 2012

Paulilo M.T.S., Duz S.R., Siminski A. et al.: Responses to light changes in tropical seedlings of the Brazilian Atlantic rainforest tree species Cecropia glazioui (Cecropiaceae) and Cedrela fissilis (Meliaceae). - Aust. J. Bot. 55: 795-802, 2007.

Prado Júnior J.A., Lopes S.F., Vale V.S. et al.: Floristic patterns in understoreys under different disturbance severities in seasonal forests. - J. Trop. Forest Sci. 26: 458-468 2014

Press W.H., Teukolsky S.A., Vetterling W.T. et al.: Numerical Recipes in Fortran 77: the Art of Scientific Computing. Pp. 963. Cambridge University Press, Cambridge 1992.

Putz F.E.: The natural history of lianas on Barro Colorado Island, Panama. - Ecology 65: 1713-1724, 1984.

Rabelo G.P., Vitória A.P., Silva M.V.A. et al.: Structural and ecophysiological adaptations to forest gaps. - Trees 27: 259272, 2013.

Roháček K.: Chlorophyll fluorescence parameters: the definitions, photosynthetic meaning, and mutual relationships. - Photosynthetica 40: 13-29, 2002.

Restom T.G., Nepstad D.C.: Contribution of vines to the evapotranspiration of a secondary forest in eastern Amazonia. - Plant Soil 236: 155-163, 2001.

Sanches M.C., Marzinek J., Bragiola N.G. et al.: Morphophysiological responses in Cedrela fissilis Vell. submitted to changes in natural light conditions: implications for biomass accumulation. - Trees 31: 215-227, 2017.

Sanches M.C., Válio I.F.M.: Seedling growth of climbing species from a southeast Brazilian tropical forest. - Plant Ecol. 154: $51-59,2002$

Sanches M.C., Válio I.F.M.: Leaf optical properties of two liana species Canavalia parviflora Benth. and Gouania virgata Reissk. in different light conditions. - Rev. Bras. Bot. 29: 319-330, 2006

Sanches M.C., Válio I.F.M.: Photosynthetic response of two tropical liana species grown under different irradiances. Photosynthetica 46: 557-566, 2008.

Santos K., Kinoshita L.S., Rezende A.A.: Species composition of climbers in seasonal semideciduous forest fragments of Southeastern Brazil. - Biota Neotrop. 9: 175-188, 2009.

Schnitzer S.A., Bongers F.: Increasing liana abundance and biomass in tropical forests: emerging patterns and putative mechanisms. - Ecol. Lett. 14: 397-406, 2011.

Schnitzer S.A., Carson W.P.: Lianas suppress the regeneration and diversity in treefall gaps. - Ecol. Lett. 13: 849-857, 2010.

Schnitzer S.A., Dalling J.W., Carson W.P.: The impact of lianas on tree regeneration in tropical forest canopy gaps: evidence for an alternative pathway of gap-phase regeneration. - J. Ecol. 88: 655-666, 2000.

Sokal R.R., Rohlf F.J.: Biometry. The Principles and Practice of Statistics in Biological Research. Pp. 859. WH Freeman and
Company, New York 1981.

Souza F.M., Gandolfi S., Rodrigues R.R.: Deciduousness influences the understory community in a semideciduous tropical forest. - Biotropica 46: 512-515, 2014.

Souza R.P., Válio I.F.M.: Seedling growth of fifteen Brazilian tropical tree species differing in successional status. - Rev. Bras. Bot. 26: 35-47, 2003.

Takahashi S., Murata S.: How do environmental stresses accelerate photoinhibition? - Trends Plant. Sci. 13: 178-182, 2008.

Tobita H., Utsugi H., Kitao M. et al.: Variation in photoinhibition among Sasa senanensis, Quercus mongolica, and Acer mono in the understory of a deciduous broad-leaved forest exposed to canopy gaps caused by typhoons. - Trees 24: 307-319, 2010.

Toledo-Aceves T., Swaine M.D.: Effect of three species of climber on the performance of Ceiba pentandra seedlings in gaps in a tropical forest in Ghana. - J. Trop. Ecol. 23: 45-52, 2007.

Toledo-Aceves T., Swaine M.D.: Biomass allocation and photosynthetic responses of lianas and pioneer tree seedlings to light. - Acta Oecol. 34: 38-49, 2008.

Toniato M.T.Z., Oliveira-Filho A.T.: Variations in tree community composition and structure in a fragment of tropical semideciduous forest in southeastern Brazil related to different human disturbance histories. - Forest Ecol. Manage. 198: 319-339, 2004

Valladares F., Chico J.M., Aranda I. et al.: The greater seedling high-light tolerance of Quercus robur over Fagus sylvatica is linked to a greater physiological plasticity. - Trees 16: 395403, 2002.

Vasconcelos T.N.C., Silva J.S., Ianhez M.L. et al.: Floristic survey of the Brazilian Ages Memorial: a Cerrado sensu stricto area with an educational relevance. - Check List 11: 1-9, 2015.

Vargas B.C., Araujo G.M.: [Floristics of climbing plants in semideciduous forest fragments at Uberlândia, Minas Gerais, Brazil.] - Rodriguésia 65: 49-59, 2014. [In Portuguese]

Venturoli F., Franco A.C., Fagg C.W. et al.: [Light availability in a semideciduous forest management in Pirenópolis, Goiás, Brazil] - Rev. Árvore 36: 1135-1144, 2012. [In Portuguese]

White A.J., Critchley C.: Rapid light curves: a new fluorescence method to assess the state of the photosynthetic apparatus. Photosynth. Res. 59: 63-72, 1999.

Wirth R., Weber B., Ryel J.R.: Spatial and temporal variability of canopy structure in a tropical moist forest. - Acta Oecol. 22: 235-244, 2001.

Wyka T.P., Oleksyn J., Karolewski P. et al.: Phenotypic correlates of the lianescent growth form: a review. - Ann. Bot.-London 112: 1667-1681, 2013.

Yamashita N., Ishida A., Kushima H. et al.: Acclimation to sudden increase in light favoring an invasive over native trees in subtropical islands, Japan. - Oecologia 125: 412-419, 2000.

Yuan C.M., Wu T, Geng Y.F. et al.: Phenotypic plasticity of lianas in response to altered light environment. - Ecol. Res. 31: 375 384, 2016.

Zhang S.B., Zhang J.L., Cao K.F.: Differences in the photosynthetic efficiency and photorespiration of cooccurring Euphorbiaceae liana and tree in a Chinese savanna. - Photosynthetica 54: 438-445, 2016.

Zhou R., Su W.H, Zhang G.F. et al:: Relationship between flavonoids and photoprotection in shade-developed Erigeron breviscapus transferred to sunlight. - Photosynthetica 54: 201-209, 2016.

(C) The authors. This is an open access article distributed under the terms of the Creative Commons BY-NC-ND Licence. 